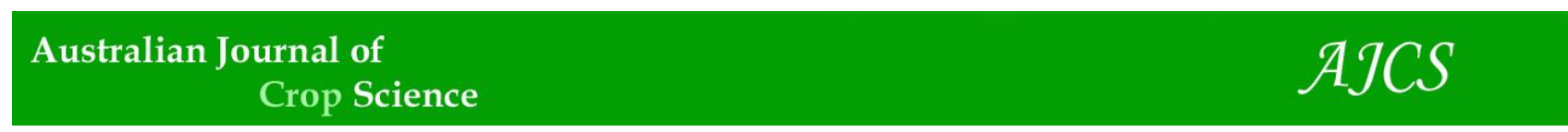

AJCS 11(09):1195-1202 (2017)

ISSN:1835-2707

doi: 10.21475/ajcs.17.11.09.pne543

\title{
Spray droplet spectrum and spray deposition in different soybean sowing systems
}

\author{
Raniele Tadeu Guimarães Souza $^{1 *}$, Itamar Rosa Teixeira ${ }^{1}$, Flivia Fernandes Jesus ${ }^{2}$, Elton Fialho Reis ${ }^{1}$ \\ ${ }^{1}$ State University of Goiás, Henrique Santillo Campus (CCET), Zip Code: 459, Post Code: 75132-400, Anápolis, \\ Brazil \\ ${ }^{2}$ University of Brasília, Department of Agronomy, Darcy Ribeiro Campus, Zip Code: 04357, Post Code: 70904- \\ 970, Asa Norte, Brasilia/DF, Brazil
}

\section{*Corresponding author: raniele.souza1 @ gmail.com}

\begin{abstract}
Soybean, Glycine $\max$ (L.) Merrill, can adapt to the environment and management alterations, in particular to the use of different spacings and plant populations. This paper aimed at checking the influence of the morphological changes of soybean plants grown in the cross sowing systems on the spray droplet spectrum and spray deposition. The experiment was conducted in the summer of 2013/2014 harvest season, using the randomized block design with factorial arrangement of 2 × 3 × 3, being two sowing systems (cross and in line), three cultivars (BRS Valiosa RR with determinate growth habit, NA 7337 RR with semi-determinate growth habit and BMX Potencia RR with indeterminate growth habit) and three sowing densities $\left(245,000 ; 350,000\right.$ and 455,000 plants per ha $\left.{ }^{-1}\right)$. To study the spray deposition, it was applied a solution composed of water and brilliant blue marking dye (FCF blue dye, Duas Rodas Ltd.), after the application, four leaves of each soybean were collected from their parts (lower, middle, higher) in five plants per plot. The results showed that the cross sowing system provided lager canopy closure between lines 50 days after soybean emergence, facilitated by the population increase. There is a difference in the droplet deposition in the canopy parts of the plant on both sowing systems. The cultivar with semi-determinate growth habit, NA 7337 RR, allowed better spray deposition in the lower plant parts. The cross sowing system does not interfere with spraying quality in relation to the conventional system (in line).
\end{abstract}

Key words: Glycine max, spatial arrangement of plants, growth habit, application technology of protection products. Abbreviations: LAI_Leaf area and leaf area index, DAS_days after sowing, MVD_ Median volume diameter), NMD_numeric median diameter, RA_relative amplitude, COV_covering.

\section{Introduction}

Soybean (Glycine $\max (\mathrm{L}$.$) Merrill) is admittedly the most$ commercially important legume in the world. However, production and consumption are very close, the 2013/14 harvest having produced 283.79 million tons of which 269.89 million tons were consumed, the final global stock being of 66.98 million tons (Usda, 2014), which is considered low. In this regard, adoption and application of new technologies and research will allow increasing productivity and production, which is a major factor for safeguarding food security.

Studies on the adequacy of soybean plant spatial distribution to the growing area have aroused interest in the last years, motivated by the increased grain yield per agricultural unit, due to the capacity of the soybean plant to adapt to different types of cultivation, a characteristic which is known as phenotypic plasticity (Heiffig et al., 2006). In this regard, various studies were conducted on the spatial distribution of the soybean plants in the cultivation area, in particular on the spacing and population density variations (De Bruin and Pedersen, 2008; Cox and Cherney, 2011). However, due to the dynamism of the soybean breeding programs, which contributes to the annual launch of genetic materials with the most diverse growth habits on the markets, frequent evaluation of such materials in the existing cultivation systems becomes necessary.
Spacing and population density variation promotes changes in the plant morphology, in the number of pods per plant, resulting from the lower number of branches, (Carpenter and Board, 1997), besides promoting changes in the leaf area and leaf area index, resulting from the increase and decrease in the number of branches per plant. It must be observed that plant architecture has a direct influence on the efficiency of the application technology of agrochemicals. Tormen et al. (2012) verified that soybean cultivars with higher LAI and more lateral ramifications close the canopy faster and make the penetration of the water droplets into the bottom of the plant difficult. Ozkan et al. (2007) also verified that with a LAI of 6.4 most droplets are retained in the upper canopy, facilitating the proliferation of diseases in the lower canopies, which are chemically unprotected and have a favorable microclimate. Cunha et al., 2014 highlight the need for searching strategies that increase the spray deposition at the lower parts of the plant, considering the defense application methods that are difficult to cover in the area.

Recent studies with cross sowing, a special type of spatial distribution of plants on the growing area, showed promising results in terms of productive increase, but it is still insufficiently studied and explored with regard to morphologic changes of the plant and their influence on the application of crop protection products (Lima et al., 2012). 
Souza et al., 2016 demonstrated that at the fifth day after the emergence the cross sowing system provided lager canopy closure, when compared to the line sowing system, promoted by the population increase, which might affect directly the spray droplet spectrum.

Disease control and efficiency of coverage and spray deposition must be evaluated, since the rapid increase in leaf area in the upper parts of the plant influences the maintenance of a microclimate favorable for the multiplication of the pathogenic agent, caused by high humidity, lesser air circulation and lower light incidence. The location of the initial stages of diseases requires that applications overcome the leaf mass and favor a good coverage inside the plant (Raetano, 2007; Zhu et al., 2008; Debortoli et al., 2012). In this regard, for application of crop protection products, two aspects of the technology must be noted: spray deposition, i.e. the amount of active ingredient that reaches the part to be treated, and application quality, related to the appearance of the droplets, for the droplets to be produced must have homogeneous size, preventing losses by drift or drainage (Figueiredo et al., 2007), therefore, the adequate use of this technology is essential to increase the efficiency of plant protection products and minimize the contamination of application operators and the environment, as well as the reduction of the application costs (Balan et al., 2016). This study aimed at checking the influence of the morphological changes of soybean plants grown in the cross sowing systems on the spray droplet spectrum and spray deposition, observing the interference of the systems, different populations and plant architecture over the soybean culture and spray droplet spectrum and spray deposition, preponderant factors to determine the quality of the application technology.

\section{Results and Discussion}

Data showed significant differences for the analyzed variables, regarding the droplet spectrum, aqueous solution deposition and agronomic characteristics.

\section{Closure rate of the interlines is affected by the system and sowing density and by the growth patterns}

The analysis of variance for the crop closure rate was influenced by the sowing system, growth habit and sowing density factors, at the six evaluation moments before total crop closure. All treatments got $100 \%$ closure between lines, at 55 DAS. However, evaluations showed some behavior variation during that period, as observed in the significant differences within each evaluation.

At 30 and 35 DAS, the conventional sowing system (line) showed faster closure than the cross system. However, in the cross sowing system, the closure between lines intensified after 45 DAS (T4), differing significantly from the in-line system at 50 DAS at the T5 moment (Table 1), being 9.56\% more closed. At 55 DAS (T6 moment), the cross sowing was already $100 \%$ closed, while the percentage of the in-line sowing was $90 \%$. We observed that the leaf area index of the cross sowing system is $7 \%$ higher than that of the in-line system, which can justify better closure in the cross system.

Faster canopy closure in cross sowing systems was also observed by Câmara et al. (2012), who stressed that in this condition, the crop precociously reaches the phase of maximum growth. Spacing reduction and more equidistant spacings allow increase in light use efficiency at the early stages of crop development, thanks to higher leaf area index and phytomass production, and consequently higher productivity (Cox and Chemey, 2011). Studies like Gazziero and Souza (1993), and Heiffig et al. (2006) agree that faster crop closure is extremely important for weed control, due to greater soil shading between the lines.

In relation to growth habit, all observations showed that the semi-determinate growth cultivar (NA $7337 \mathrm{RR}$ ) had a higher closure rate than the indeterminate growth cultivar (BMX Potência RR). The determinate growth cultivar (BRS Valiosa RR) showed higher branching capacity, leaf area and leaf area index. On the other hand, the semi-determinate growth cultivar, even with lower branching, leaf area and leaf area index, proved efficient in the closure capacity between lines, a characteristic associated with better leaf distribution of the cultivar.

Increase in sowing density influenced the closure rate during the evaluation period. The higher the sowing density, the higher the closure between lines (Table 1). In a study about spacing and population density, Heiffig et al. (2006) observed a faster closure in the treatments made up of lower spacings and higher densities, supporting the results obtained. However, they also point out that fast closure between lines could provide a microclimate favoring the occurrence of diseases.

\section{Agricultural defensive application technology}

\section{Evaluations before application}

The leaf area characteristic was influenced by the growth habit and sowing density factors, while LAI was influenced only by the growth habit of the cultivar. According to Liu et al. (2010), soybean growth habit influences several agronomic characteristics, such as plant height, lodging resistance, branch number, among others, which can consequently influence leaf area and LAI. As for changes of leaf area in relation to population density, several studies confirm its influence on the characteristics of soybean plants, in particular on the morphological and yield changes (Heiffig et al., 2006; De Bruin and Pedersen, 2008; Holtz et al., 2013). There was no influence of the sowing system on the leaf area or on LAI, which demonstrates that, in the present situation, spatial distribution did not cause morphological changes in the plant architecture. Such results are relevant for matters of shading, leaf senescence in the lower parts and setting of flowers and pods (Madalosso, 2010), being also positive in the plant health control (Câmara, 1998; Costa et al., 2002).

The determinate growth habit cultivar showed higher values of leaf area $-19.83 \%$ and LAI $-15.7 \%$ in relation to the indeterminate and semi-determinate growth habit cultivars, which can be explained by the higher number of side branches observed in the determinate growth cultivar. According to Borém (2000), each growth habit influences differently the size of the soybean plant, but the plant structure depends mainly on the environmental conditions and on the genotype of the cultivar or variety.

We observed that the response of the leaf area was opposite to the increase in population density per area, i. e., there was an increase in population and a decrease in leaf area. Something similar was observed by Procópio et al. (2013), when analyzing the dry mass of leaves and branches per plant, which decreases with density change from 375,000 seeds $\mathrm{ha}^{-1}$ to 562,500 seeds ha $^{-1}$, resulting from less competition between soybean plants for water, light and nutrients, allowing higher growth per plant in a smaller population. 
On the other hand, the leaf area index was not modified by the different population levels, since this index receives compensation between the ratio leaf area and number of plants per area, resulting from the high capacity of morphological adaptation of soybean. Such results differ from Heiffig et al. (2006), who verified increases in leaf area index with population change from 70,000 to 350,000 plants. It should be noted that plant population density per area plays a key role in the configuration of the plant architecture, and it is currently verified that the indication of suited cultivars is made by taking five characteristics into account: soil fertility level, development cycle, growth habit, sowing period and population density. Moreover, Debortoli et al. (2012) consider that the current trend is to use smaller soybean cultivars, with higher branching and lower leaf area index, thus increasing the need for tissue protection to achieve the highest productivity, which makes definition of the adequate population of plants to be used a factor of utmost importance.

Medium volumetric diameter (MVD), relative amplitude $(\mathrm{RA})$ and droplet coverage (COV), under the influence of cultivar systems, sowing density and growth habits of the soybean seedling

In the droplet spectrum evaluation, sowing system, growth habit and sowing density did not influence MVD and COV. But RA was influenced by the interaction between sowing system and cultivar. We also verified the occurrence of quite high variation coefficients for MVD (28.89\%), RA (31\%) and COV $(53.81 \%)$, which Holtz et al. (2014) attributes to the methodology for determination of the droplet spectrum with labels of water-sensitive paper, which presents a high variation coefficient resulting from its sampling dimensions. However, we verified significant influence of the parts in the plant canopy on all variables response, MVD, COV, RA and deposition.

By means of the values obtained for droplet spectrum and droplet population, it was possible to identify the average of 171.27 of MVD (Table 4), allowing the classification as thin droplets. According to the BCPC (British Crop Production Council), the MVD for thin droplets corresponds to the interval between 119 and $216 \mu \mathrm{m}$, for average droplets between 217 and $352 \mu \mathrm{m}$, and for thick droplets between 354 and $464 \mu \mathrm{m}$. But for the ASE (American Society of Agricultural Engineering) the interval for thin droplets is between 150 and $250 \mu \mathrm{m}$, for average droplets between 350 and $450 \mu \mathrm{m}$ and for thick droplets between 350 and $450 \mu \mathrm{m}$ (Brown-Rytlewski and Saton, 2007). The occurrence of thinner droplets is requested for a better coverage of the leaf area, but a high percentage of very thin droplets is susceptible of drift, as, according to Cunha et al. (2004), safe application requires a percentage of droplets thinner than $100 \mu \mathrm{m}$ inferior to $15 \%$ of the sprayed volume.

Average MVD results are considered suitable for application of systemic fungicides (Ozkan et al., 2007; Vásques Minguela and Cunha, 2010), as fungicide application quality is related to the occurrence of droplets of lower MVD for presenting higher speed of fungicide uptake due to the higher number of droplets per square centimeter (Balardin et al., 2011).

Interaction between cross sowing system and indeterminate growth habit presented the highest average for relative amplitude (Table 2). However, within the sowing system the growth habit had no influence on the relative amplitude. According to Silva (2009), relative amplitude defines the uniformity of the droplet set or the variation spectrum of the droplet size, the homogeneous droplet spectrum having a relative amplitude tending to zero (Viana et al., 2010). It was then possible to verify that, in the cross sowing system, RA is strongly influenced by the semi-determinate growth habit cultivar.

Application quality was strongly influenced by the plant canopy, in which the higher parts presented the highest averages, whereas the lower part presented the lowest averages for MVD, RA and COV (Table 3). Such results confirm Debortoli et al. (2012), who observed an imbalance in the distribution of the fungicide dose along the plant canopy, the higher part having received 2.5 times, while the lower part received $1 / 3$ of the necessary dose to control diseases.

Droplets with higher MVD were produced in the higher part of the plant, with reduction of $20.64 \%$ for the middle part and of $35.14 \%$ from the higher to the lower part. Such results agree with Bretthauer et al. (2008), who verified a reduction of $12.1 \%$ in the MVD from the higher to the lower part when evaluating the spectrum of medium and thick droplets. Two other studies looked for answers on this subject: $\mathrm{Yu}$ et al. (2009) confirmed influence of relative humidity on the droplet size reduction, which was 10 times faster when comparing droplets with $246 \mu \mathrm{m}$ and $800 \mu \mathrm{m}$ with $60 \%$ of relative humidity and reduction of MVD in the middle and lower part of the canopy. Such results agree with Debortoli et al. (2012), who consider that localization in the canopy can promote overlap of droplets in the labels placed in the higher part, due to higher droplet density.

In the higher part, we verified more uneven droplets, as observed in Table 4, in relation to RA under the climatic conditions during the application. But in the middle and lower parts, there was no significant difference, which suggests better application uniformity, RA averages being lower, which improved quality in the relation between thick and thin droplets.

The averages obtained by the coverage or covered area were higher for the higher part, with $70 \%$ above the middle part and $82 \%$ above the lower part (Table 4). Such values were higher than those obtained by Hanna et al. (2008), who found spray coverage with $50 \%$ or more in the higher part, and $20 \%$ or less in the lower part, with layers of $30 \mathrm{~cm}$. In a study on soybean rust control, Cunha and Peres (2010) obtained a highly uneven coverage in relation to the parts of the plants, with higher deposition in the higher than in the lower part. Such results warn about the correct moment of application in the control, mainly of soybean diseases like soybean rust, observing the need for preventive applications before total closure of the plant canopy.

\section{The canopy of the plants influenced on the deposition of the} aqueous solution

Regarding the variable answer of the aqueous solution deposition, it was verified that, beyond the influence of the canopy, there was a significant difference during the factors interaction: parts of the canopy the plant, growth habits and sowing system (Table 4).

Thus, with the results obtained in the droplet spectrum, the upper part of the canopy presented better averages for deposition $(0,01221 ; 0,00575$ e 0,00408 , respectively for the upper, medium and inferior parts of the canopy the plant), both in relation to growth habit and to sowing system. The deposition average decreased significantly in the medium and inferior part of the canopy. The higher part of the canopy considering the growth habits showed the larger deposition average, 0,01221 , for the same cultivar, it was observed a lower deposition average in the lower part $-66 \%$. The 
Table 1. Average values of crop closure (LA), obtained before the application of agrochemicals in function of the different soybean growing systems, growth habits and sowing density. UEG, Anápolis, 2014.

\begin{tabular}{|c|c|c|c|c|c|c|}
\hline \multirow{2}{*}{$\begin{array}{l}\text { Factors under study } \\
\text { Sowing system }\end{array}$} & \multicolumn{6}{|c|}{ Closure rate of the interlines } \\
\hline & T1 & $\mathrm{T} 2$ & T3 & T4 & T5 & T6 \\
\hline In line & $47.6 \mathrm{a}$ & $55.4 \mathrm{a}$ & $58.5 \mathrm{a}$ & $60.4 \mathrm{a}$ & $71.2 \mathrm{~b}$ & $90.0 \mathrm{a}$ \\
\hline Cross & $44.2 \mathrm{~b}$ & $52.4 \mathrm{~b}$ & $57.18 \mathrm{a}$ & $62.7 \mathrm{a}$ & $78.0 \mathrm{a}$ & $90.0 \mathrm{a}$ \\
\hline \multicolumn{7}{|l|}{ Growth habit } \\
\hline Determinate & $44.5 b$ & $53.4 \mathrm{a}$ & $58.1 \mathrm{a}$ & $65.6 \mathrm{a}$ & $77.0 \mathrm{a}$ & $90.0 \mathrm{a}$ \\
\hline Semi-determinate & $48.4 \mathrm{a}$ & $54.4 \mathrm{a}$ & $58.9 \mathrm{a}$ & $62.5 \mathrm{a}$ & $76.1 \mathrm{a}$ & $90.0 \mathrm{a}$ \\
\hline Indeterminate & $44.9 \mathrm{~b}$ & $53.2 \mathrm{a}$ & $56.5 b$ & $56.5 b$ & $70.6 \mathrm{~b}$ & $90.0 \mathrm{a}$ \\
\hline \multicolumn{7}{|l|}{ Sowing density } \\
\hline 245,000 & $43.7 b$ & $52.6 \mathrm{~b}$ & $55.2 \mathrm{c}$ & $58.7 \mathrm{a}$ & $71.6 \mathrm{~b}$ & $90.0 \mathrm{a}$ \\
\hline 350,000 & $45.6 \mathrm{~b}$ & $53.6 \mathrm{~b}$ & $58.1 \mathrm{~b}$ & $62.7 \mathrm{a}$ & $75.5 \mathrm{a}$ & $90.0 \mathrm{a}$ \\
\hline 455,000 & $48.4 \mathrm{a}$ & $55.4 \mathrm{a}$ & $60.3 \mathrm{a}$ & $63.2 \mathrm{a}$ & $76.7 \mathrm{a}$ & $90.0 \mathrm{a}$ \\
\hline Average & 45.9 & 53.9 & 57.8 & 61.5 & 74.6 & 90.0 \\
\hline
\end{tabular}

Averages followed by the same letter in the column do not differ according to Scott-Knott test at $5 \%$ probability.

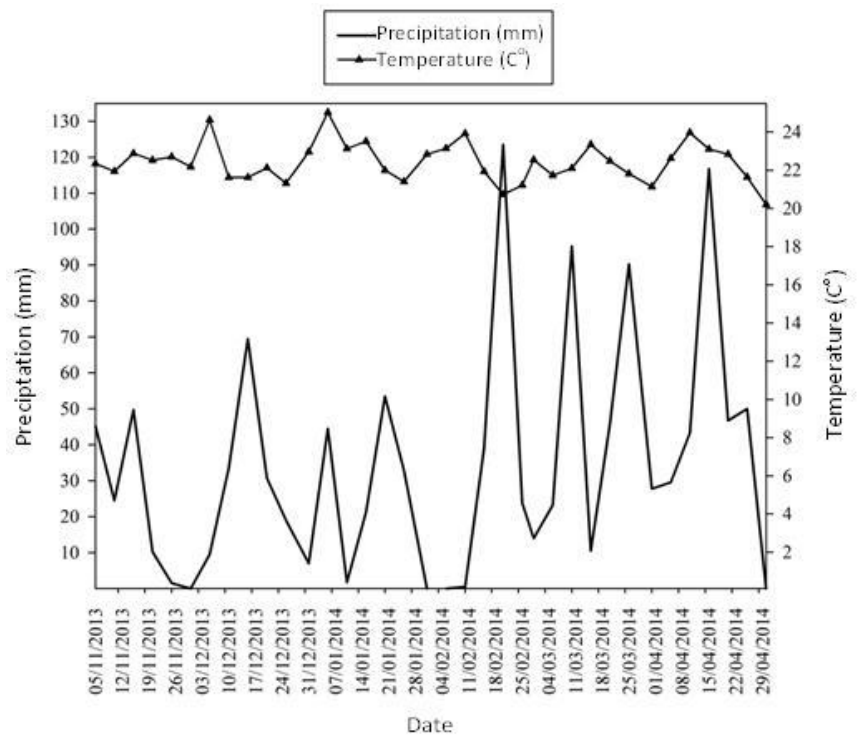

Fig 1. Rainfall distribution and daily average air temperature during experimentation period.

Table 2. Average values of relative amplitude (RA) in function of the growth habit of soybean cultivars and sowing system. UEG, Anápolis, 2014

\begin{tabular}{lcc}
\hline Growth habit & Conventional & Cross \\
\cline { 2 - 3 } & $1.183 \mathrm{Aa}$ & $1.128 \mathrm{Aa}$ \\
Determinate & $1.061 \mathrm{Ba}$ & $1.271 \mathrm{Aa}$ \\
Semi-determinate & $1.139 \mathrm{Aa}$ & $1.085 \mathrm{Aa}$ \\
Indeterminate & & $1.00 \mathrm{a}$ \\
Average followed by the same uppercase letter in the line and the same lowercase letter in the column do not differ statistically according to Scott-Knott test at 5\% \\
probability.
\end{tabular}

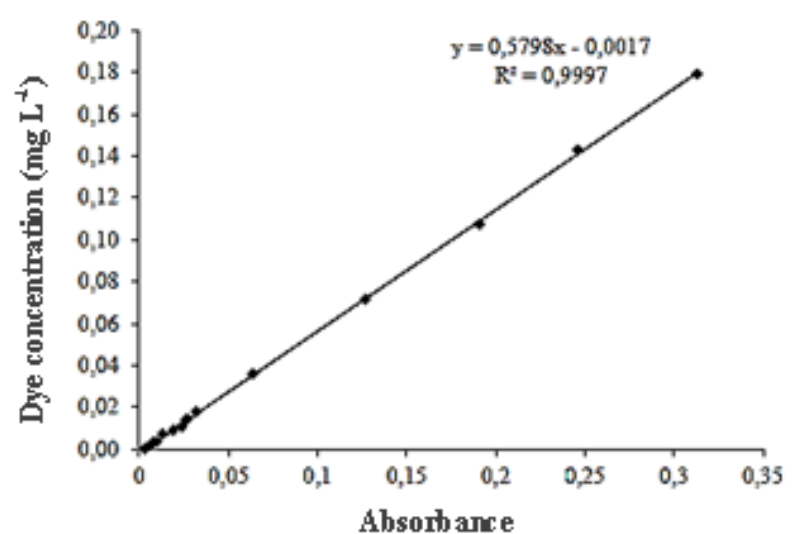

Fig 2. Calibration curve for brilliant blue food dye (FCF Blue Dye, Duas Rodas Industrial) (FD\&C Blue No. 1). 
Table 3. Average values of volumetric median diameter (MVD), relative amplitude (RA) and droplet coverage (COV), in function of the canopy parts within the soybean plant canopy. UEG, Anápolis, 2014

\begin{tabular}{lccc}
\hline \multirow{2}{*}{ Canopy Parts } & & Evaluated characteristics & RA \\
\cline { 2 - 4 } & MVD $(\mu \mathrm{m})$ & $1.23 \mathrm{a}$ & $18.24 \mathrm{a}$ \\
Higher & $210.41 \mathrm{a}$ & $1.14 \mathrm{~b}$ & $5.54 \mathrm{~b}$ \\
Middle & $166.97 \mathrm{~b}$ & $1.07 \mathrm{~b}$ & $3.21 \mathrm{c}$ \\
Lower & $136.44 \mathrm{c}$ & & COV \\
\hline
\end{tabular}

Averages followed by the same letter in the column did not differ statistically according to Scott-Knott test at 5\% probability.

Table 4. Average values of the spray deposition in the interactions on the canopy parts, sowing system and growth habits of the soybean cultivars. UEG, Anápolis, 2014.

\begin{tabular}{|c|c|c|c|c|c|}
\hline \multirow{2}{*}{ Canopy Parts } & \multicolumn{3}{|c|}{ Growth habit } & \multicolumn{2}{|c|}{ Sowing system } \\
\hline & Determinate & Semi-determinate & Indeterminate & Conventional & Cross \\
\hline Higher & $0.01221 \mathrm{Aa}$ & $0.01083 \mathrm{Ba}$ & $0.01177 \mathrm{Aa}$ & $0.0111 \mathrm{Ba}$ & $0.0121 \mathrm{Aa}$ \\
\hline Middle & $0.00575 \mathrm{Ab}$ & $0.00655 \mathrm{Ab}$ & $0.00630 \mathrm{Ab}$ & $0.0067 \mathrm{Ab}$ & $0.0057 \mathrm{Bb}$ \\
\hline Lower & $0.00408 \mathrm{Ac}$ & 0.00488 Ac & $0.00464 \mathrm{Ac}$ & $0.0046 \mathrm{Ac}$ & $0.0045 \mathrm{Ac}$ \\
\hline
\end{tabular}

Averages followed by the same uppercase letter in the line and the same lowercase letter in the column do not differ statistically according to Scott-Knott test at $5 \%$ probability.

Table 5. Weather conditions during application (period from to 2 to $5 \mathrm{pm}$ ).

\begin{tabular}{lccc}
\hline Weather condition & Minimum & Maximum & Average \\
\hline Air temperature $\left({ }^{\circ} \mathrm{C}\right)$ & 34.4 & 38.2 & 36.65 \\
Relative humidity $(\%)$ & 36.0 & 45.0 & 41.25 \\
Wind speed $\left(\mathrm{m} \mathrm{s}^{-1}\right)$ & 1.0 & 1.95 & 1.52 \\
\hline
\end{tabular}

average results for the deposition in the inferior part of the canopy did not differ for the cultivars and sowing system, attributing lower values for deposition in the lower part of the plant.

Results regarding leaf area and leaf area index show significant higher values of the determinate growth habit material in relation to semi-determinate and indeterminate growth habit cultivars, and thus the leaf mass in the plant canopy influenced spray deposition in the lower parts. According to Tormen et al. (2012), the leaves of the plant top intercept a considerable part of the sprayed droplets, preventing the lower leaves from receiving significant amounts of active ingredient in the plant health control. Therefore, the plant lower part is highly dependent on the plant architecture, as well as leaf area and LAI. The results corroborate those of Souza et al. (2003) on the influence of architecture in the application technology of crop protection products.

The semi-determinate growth habit cultivar (NA 7337 RR) presented lower average in the higher part in relation to deposition in the other cultivars. In relation to the other parts, there was no significant effect in relation to the other cultivars. This suggests that the semi-determinate growth cultivar, NA 7337 RR, has a better spray distribution for having better architecture and canopy distribution. The same cultivar also presented lower leaf area and leaf area index.

The cross sowing system presented better deposition average in the higher part, followed by the middle part and lower part, respectively (Table 5). This system also presented higher averages for leaf area and leaf area index. However, the conventional sowing system presented a significantly better average deposition in the middle part which suggests that the higher part presented lesser impediment to deposition of the middle and lower parts (Table 5). According to Cunha and Peres (2010), special attention must be given to diseases with initial development in the bottom of the plants, like soybean rust, since application deficiencies may compromise crop development.
The results obtained demonstrated that architecture influenced the aqueous solution deposition, as observed in the spray deposition between the plant canopies. As to factors like leaf area and LAI, it is necessary, when choosing the cultivation system, to perfectly adjust the cultivar and sowing density. Such behaviors agree with Debortoli et al. (2012), who affirm there is a tendency to choose cultivars with lower leaf area index, primarily.

\section{Materials and Methods}

\section{Characterization of the experimental area}

The experiment was conducted in the summer harvest of 2013/2014, in an experimental area pertaining to Emater-GO, unit of Anápolis-GO, whose geographic coordinates are: $48^{\circ} 18^{\prime} 23^{\prime \prime} \mathrm{W}$ and $16^{\circ} 19^{\prime} 44^{\prime \prime} \mathrm{S}$, at a height of $1,017 \mathrm{~m}$. The predominant climate in the region is the Aw tropical wet, according to Köppen classification, characterized by dry winter and wet summer. The installation of the experiment was carried out on the 12th of November 2013, the climatic conditions prevailing during the experiment conduction being shown in Figure 1.

The soil of the area classified as dystrophic red oxisol was sampled in the 0-20 cm layer, and the results of the chemicalphysical analyses were: $\mathrm{pH} 5.5$; organic matter $31 \mathrm{~g} \mathrm{dm}^{-3} ; \mathrm{P}$ $4.3 \mathrm{mg} \mathrm{dm}^{-3} ; \mathrm{K} 36 \mathrm{mg} \mathrm{dm}^{-3}$; $\mathrm{Ca} 2.7 \mathrm{cmolc} \mathrm{dm}^{-3} ; \mathrm{Mg} 0.8$ cmolc dm ${ }^{-3}$; Al $0.0 \mathrm{cmolc} \mathrm{dm}^{-3}$; B $0.19 \mathrm{mg} \mathrm{dm}^{-3}$; $\mathrm{Cu} 4.0 \mathrm{mg}$ $\mathrm{dm}^{-3}$; Fe $42.1 \mathrm{mg} \mathrm{dm}^{-3}$; Mn $10.3 \mathrm{mg} \mathrm{dm}^{-3}$; Mo $0.09 \mathrm{mg} \mathrm{dm}^{-3}$; Zn $3.0 \mathrm{mg} \mathrm{dm}^{-3}$; clay $30 \%$; sand $62 \%$ and silt $0.8 \%$.

\section{Experimental design and treatments}

We used the completely randomized block design with factorial arrangement of $2 \times 3 \times 3$, with three replications. The treatments consisted of two sowing systems (cross and in-line), three soybean cultivars with different growth habits 
and types (BRS Valiosa RR - determinate; BMX Potência RR - indeterminate; and NA 7337 RR - semi-determinate), combined with three sowing densities (D1: 245,000 plants ha ${ }^{-}$

${ }^{1}$; D2: 350,000 plants ha ${ }^{-1}$; and D3: 455,000 plants ha' ${ }^{-1}$ ).

\section{Setting up and conduction}

The plots consisted of five rows of $5 \mathrm{~m}$ in length, spaced $0.45 \mathrm{~m}$ apart. The useful area consisted of the three central lines, disregarding $1 \mathrm{~m}$ at each end.

The soil preparation was conventional, with one plowing and two harrowings. Later, basic fertilizing was carried out in accordance with soybean growing recommendation, aiming at getting a yield of $3,000 \mathrm{~kg} \mathrm{ha}^{-1}$ (Embrapa, 2008). The amount of $400 \mathrm{~kg} \mathrm{ha}^{-1}$ of NPK 04-30-16 formula was applied. The seeds were initially treated with carbendazim $(15 \%)+$ tiram (35\%) fungicide, at a dose of $200 \mathrm{~mL}$ for $100 \mathrm{~kg}$ of seeds, then inoculated with a bacterium of the type Bradyrhizobium elkanii (semia 587) and Bradyrhizobium japonicum (semia 5079), with a bacterial concentration of 5.0 $\mathrm{x} 109$ UFC per $\mathrm{ml}$, at a dose of $150 \mathrm{~mL}$ of the commercial product for $50 \mathrm{~kg}$ of seeds. The sowing was carried out. Moreover, we applied $24 \mathrm{~kg} \mathrm{ha}^{-1}$ of $\mathrm{K}_{2} \mathrm{O} 30$ DAS, having the potassium chloride as a source.

Weed control was carried out by application of glyphosate at $25 \mathrm{DAS}$, at the recommended dose of $3 \mathrm{~L} \mathrm{ha}^{-1}$. Six applications of the deltamethrin insecticide $(2.5 \%)$ at a dose of $300 \mathrm{ml} \mathrm{ha}^{-1}$ were carried out to control velvetbean caterpillar (Anticarsia gemmatalis), soybean looper (Pseudoplusia includens), southern green stink bug (Nezara viridula) and Piezodorus guildinii, all having a significant occurrence during the experiment. Three preventive applications of trifloxistrobin $(10 \%)+$ tebuconazole $(20 \%)-$ based fungicide at a dose of $500 \mathrm{ml} \mathrm{ha}^{-1}$ in short-cycle cultivars NA 7337 RR and BMX Potência RR, four applications in the late-cycle cultivar BRS Valiosa RR, to control powdery mildew (Erysiphe diffusa, Asian soybean rust (Phakopsora pachyrhizi), leaf blight (Cercospora kikuchii), brown spot (Septoria glycines), anthracnose (Colletotrichum truncatum) and target spot (Corynespora cassiicola). Other crop treatments were those usually applied to the crop.

\section{Evaluated characteristics}

Application was carried out at 62 DAS, when the three cultivars showed the highest plant development. Applications were carried out with a backpack sprayer pressurized with $\mathrm{CO}_{2}$ using a lance with 4 nozzles, spaced $0.50 \mathrm{~m}$ apart, with nozzle tips of Teejet TT11002 type. The working height of the lance during the application was of $0.50 \mathrm{~m}$ above the crop, with fixed working pressure of $3 \mathrm{kPa}$ and spray volume of $187 \mathrm{~L} \mathrm{ha}^{-1}$. We used a spray mix composed of water and brilliant blue marking dye (FCF blue dye, Duas Rodas Ltd.), internationally catalogued by Food, Drug \& Cosmetic as FD\&C Blue nr. 1, at $0.15 \%$, which was prepared in advance.

During spray application relative humidity was monitored by means of Minipa digital thermohygrometer (MT-240 model), and wind speed by means of Minipa digital anemometer (MDA-ll model), average values being showed below (Table 5).

\section{Crop closure time}

It was associated with percentage evaluation of the area covered by leaves until reaching $100 \%$, considering half of the space between lines covered by the leaves of each adjacent line. It was carried out through measurement with graduated scale, every five days after 30 DAS (Heiffig et al, 2006).

\section{Leaf area and leaf area index - LAI}

Leaf area determination was carried out at stage $R_{1}$ for BRS Valiosa RR cultivar and $R_{2}$ for the other genetic materials. Ten plants in the fourth line of each plot were collected randomly, according to the limits with the useful area. In the laboratory, the leaves of each plant were removed individually, distributed on white-color surface and immediately photographed using a Sony photo camera (Cyber-Shot model), with a 12.1 megapixel resolution, and reading was determined by means of "ImageJ" image software (Nih, 2012). LAI was determined by the ratio between the sum of the leaf area of the plant and the soil surface it covers, according to expression 1 :

$\mathrm{LAI}=(\mathrm{LA} \times \mathrm{ST}) / 1000$

Where:

LAI: leaf area index;

LA: average of the leaf area of the evaluated soybean plants $\left(\mathrm{m}^{2}\right)$;

ST: final stand of plants per hectare.

\section{Evaluation of the application efficiency in the Spray Droplet Spectrum}

To determine the droplet spectrum, water-sensitive labels were used, placed in three different positions within the useful area of each plot. To this end, metal rods were placed in the center of the plot and crop row, where labels were fixed in the upper, middle and lower parts.

After application, the labels were immediately collected, placed individually in a paper envelope, identified and taken to the Laboratory of Agricultural Engineering of the State University of Goiás for scanning, by means of a $600 \mathrm{dpi}$ Epson scanner (TX200A model). The evaluation of the droplet spectrum was carried out using the "CIR" software (Conteo y tipificación de impactos de pulverización), 1.5/2002 version. Later we determined MVD, NMD, RA and COV.

In the analyses of spray mix deposition, we determined the tracer amount, formed by tracer aqueous solution at a concentration of $0.15 \%$, according to methodology described by Palladini et al. (2005). Immediately after application with tracer aqueous solution, four leaves of each soybean plant part were randomly collected in five plants per plot, within the useful area. The collected leaves were packaged in plastic bags, identified according to the corresponding part of each plot, and placed in dark, bigger bags, aiming at reducing dye decomposition effect. All material was sent to the laboratory to remove tracer deposit from the leaves, using $10 \mathrm{~mL}$ of deionized water per leaf in each sample. A sample of this formed solution was used to quantify the dye deposit. After deposit removal, the leaves were photographed using a Sony camera (Cyber-Shot model), with a resolution of 12.1 megapixels to determine the leave measure area by means of the "ImageJ" image software (Nih, 2012).

Determination of tracer amount deposited in each sample was carried out using a Biospectro spectrophotometer (SP220 model), with tungsten lamp with halogen vapor and quartz cells with $10-\mathrm{nm}$ light path, in the $630-\mathrm{nm}$ wavelength region for brilliant blue. 
To determine the calibration curve, we used solutions with known concentrations of brilliant blue food dye, resulting in a regression equation (Figure 2), to quantify the field deposit. Thereafter, absorbance data from each treatment were transformed into concentration $\left(\mathrm{mg} \mathrm{L}^{-1}\right)$ and, given the initial spray concentration $\left(\mathrm{mg} \mathrm{L}^{-1}\right)$ and the dilution volume of the samples $(100 \mathrm{ml})$, we determined the volume retained in each part in the experimental treatments, in accordance with Equation 2. To determine the amount in $\mu \mathrm{L} \mathrm{cm}^{-2}$ deposited in each part, the value obtained in Equation 2 was divided by the leaf area of the sample obtained in the evaluation.

$\mathrm{C}_{\mathrm{i}}-\mathrm{V}_{\mathrm{i}}=\mathrm{C}_{\mathrm{f}}-\mathrm{V}_{\mathrm{f}}$

Where:

$\mathrm{Ci}=$ initial spray concentration $\left(\mathrm{mg} \mathrm{L}^{-1}\right)$;

$\mathrm{Vi}=$ volume retained by the target $(\mathrm{mL})$;

$\mathrm{Cf}=$ concentration detected in optical density $\left(\mathrm{mg} \mathrm{L}^{-1}\right)$;

$\mathrm{Vf}=$ dilution volume of the sample of each leaf $(\mathrm{mL})$.

\section{Statistical analysis}

Data were submitted to analysis of variance, and, when pertinent, the Scott-Knott test (5\% probability) was applied to discriminate possible differences between treatments. SISVAR 5.3 software was used to carry out statistical analyses.

\section{Conclusion}

The cross sowing system does not interfere with application quality in relation to the conventional system (in line).The cultivar with semi-determinate growth habit, NA 7337 RR, allowed better spray deposition in the lower plant parts.

\section{Acknowledgements}

To CAPES for partially financing the research and granting a scholarship to the first author. To CNPq for granting a productivity scholarship to the second author.

\section{References}

Balan MG, Saab OJGA, Ecker AEA, Migliorini GO (2016) Description of the application method in technical and scientific work on insecticides. Acta Sci Agron.38:9-17.

Balardin RS, Silva FDL, Debona D, Corte GD, Favera DD, Tormen, NR (2011) Tratamento de sementes com fungicidas e inseticidas como redutores dos efeitos do estresse hídrico em plantas de soja. Cienc Rural. 41: 11201126.

Borém, A (2000) Os riscos do escape gênico da soja no Brasil. Biotecnologia Cienc Desenvolv Encarte especial: 101-107.

Bretthauer SM, Mueller, TA, Derksen RC, Zhu H, Bode LE (2008) The effects of spray application rate and droplet size on application to control soybean rust. American Society of Agricultural and Biological Engineers. Michigan, ASABE Meeting Presentation, 9p.

Brown-Rytlewski D, Staton M (2014) Fungicide application technology for soybean rust - 2006: Field crop advisory alert. 2p, Michigan State University Extension, Department of Plant Pathology, Michigan. Available In: <www.ipm.msu.edu/cat06field/pdf/sbr_aptechnology.pdf>. Acess on: May 30, 2014.

Câmara GMS (1998) Ecofisiologia da soja e rendimento. In: Câmara GMS (ed) Soja: Tecnologia da produção. Fealq, Piracicaba. 256-277.
Carpenter AC, Board JE (1997) Growth dynamic factors controlling soybean yield stability across plant populations. Crop Sci. 37: 1520-1526.

Costa JA (2002) Redução no espaçamento entrelinhas e potencial de rendimento da soja. Rev Plantio Dir. 68: 2228.

Cox WJ, Cherney JH (2011) Growth and yield responses of soybean to row spacing and seeding rate. Agron J. 103: 123-128.

Cunha JPARC, Juliatti FC, Reis EF (2014) Tecnologia de aplicação de fungicida no controle da ferrugem asiática da soja: resultados de oito anos de estudos em Minas Gerais e Goiás. Biosc. J.30:950-957.

Cunha JPAR, Peres TCM (2010) Influência de pontas de pulverização e adjuvante no controle químico de ferrugem asiática da soja. Acta Sci-Agron. 32: 597-602.

Cunha JPAR, Teixeira MM, Vieira FV, Fernandes HF, Coury JR (2004) Espectro de gotas de bicos de pulverização hidráulicos de jato plano e de jato cônico vazio. Pesqui Agropecu Bras. 39: 977-985.

Debortoli MP, Tormen NR, Balardin RS, Favera DD, Stefanello MT, Pinto, FF, Uebel JD (2012) Espectro de gotas de pulverização e controle da ferrugem asiática da soja em cultivares com diferentes arquiteturas de planta. Pesqui Agropecu Bras. 47: 920-927.

De Bruin JL, Pedersen P (2008) Effect of row spacing and seeding rate on soybean yield. Agron J. 100: 704-710.

Embrapa - Empresa Brasileira de Pesquisa Agropecuária (2008) Cultivares de soja. Paraná, Brasil.

Figueiredo JLA, Teixeira MM, Picanço MC, Pinto FAC, Prat MH (2007) Avaliação da uniformidade de aplicação e do espectro de gotas de bicos hidráulicos. Rev Cien Tec Agropecu. 16: 47-52.

Gazziero DLP, Souza IF (1993) Manejo integrado de plantas daninhas. In: Arantes NE, Souza PIM (eds) Cultura da soja nos Cerrados. POTAFOS, Piracicaba. 183-208.

Hanna SO, Conley SP, Shaner, GE, Santini JB (2008) Fungicide application timing and row spacing effect on soybean canopy penetration and grain yield. Agron J. 100: 1488-1492.

Heiffig LS, Câmara GMS, Marques LA, Pedroso DB, Piedade SMS (2006) Fechamento e índice de área foliar da cultura da soja em diferentes arranjos espaciais. Bragantia 65: 285-295.

Holtz V, Couto, RF, Oliveira DG, Reis, EF (2014) Deposição de calda de pulverização e produtividade da soja cultivada em diferentes arranjos espaciais. Cienc Rural. 44: 13711376.

Lima SF, Alvarez RCF, Theodoro GF, Bavaresco M, Silva SK (2012) Efeito da semeadura em linhas cruzadas sobre a produtividade de grãos e a severidade da ferrugem asiática da soja. Biosci. 28: 954-962.

Liu B, Watanabe S, Uchiyama T, Kong F, Kanazawa A, Xia Z, Nagamatsu A, Arai M, Yamada T, Kitamura K, Masuta C, Harada K, Abe J (2010) The soybean stem growth habit gene dt1 is an ortholog of Arabidopsis terminal flower. Plant Physiol. 153: 198-210.

Madalosso MG, Domingues LS, Debortoli MP, Lenz G, Balardin RS (2010) Cultivares, espaçamento entrelinhas e programas de aplicação de fungicidas no controle de Phakopsora pachyrhizi Sidow em soja. Cienc Rural. 40: 2256-2261.

Nih - National Institutes Of Mental Health. (2014) ImageJ. Available at: http://rsb.info.nih.gov/ij/index.html. Acess on: January 14, 2014.

Ozkan E, Bretthauer S, Wolf R (2007) Application basics. In: Dorrance AE, Draper MA, Hershman DE (eds) Using foliar 
fungicides to manager soybean rust. Columbus, Ohio. 6170.

Palladini LA, Raetano CG, Velini ED (2005) Choice of tracers for the evaluation of spray deposits. Sc Agric. 62: 440-445.

Procópio SO, Balbinot Júnior AA, Debiasi H, Franchini JC, Panison F (2013) Plantio cruzado na cultura da soja utilizando uma cultivar de hábito de crescimento indeterminado. Agraria. 56: 319-325.

Raetano CG (2007) Assistência de ar e outros métodos de aplicação a baixo volume em culturas de baixo fuste: a soja como modelo. Summa Phytopathol. 33: 105-106.

Silva TMB (2009) Tecnologia de aplicação aérea de fungicidas na cultura do arroz irrigado. 63f. 2009. Dissertação (Mestrado em Agronomia)-Centro de Ciências Rurais, Universidade Federal de Santa Maria, Santa Maria, Brazil.

Souza R, Teixeira I, Reis E, Silva, A. (2016) Soybean morphophysiology and yield response to seeding systems and plant populations. Chilean Jar. 76: 3-8.

Souza RT, Palladini LA, Velini ED (2003). Pulverização eletrostática. Cultivar: Máquinas, Pelotas, n. 21, Caderno Técnico.
Tormen NR, Silva FDL, Debortoli MP, Uebel JD, Fávera DD, Balardin RS (2012) Deposição de gotas no dossel e controle químico de Phakopsora pachyrhizi na soja. Rev Bras Eng Agríc Ambient. 16: 802-808.

USDA - United States Department of Agriculture (2014) Agricultural world supply and demand estimates. 529:40.

Vásques-Minguela J, Cunha JPAR (2010) Manual de aplicação de produtos fitossanitários. 1st edn. Aprenda fácil, Viçosa, 588.

Viana RG, Ferreira LR, Ferreira MC, Teixeira MM, Rosell JR, Tuffi Santos LD, Machado AFL (2010) Distribuição volumétrica e espectro de gotas de pontas de pulverização de baixa deriva. Planta Daninha 28: 439-446.

Yu Y, Zhu H, Ozkan HE, Derksen RC, Krause CR (2009) Evaporation and deposition coverage area of droplets containing insecticides and spray additives on hydrophilic, hydrophobic, and crabapple leaf surfaces. Trans ASABE. 52:39-49.

Zhu H, Derksen RC, Ozkan HE, Reding ME, Krause CR (2008) Development of a canopy opener to improve spray deposition and coverage inside soybean canopies. 2 Opener design with field experiments. Trans ASABE. 51: 19131922. 